\title{
Heat mitigation strategies in winter and summer: field measurements in temperate climates
}

\author{
Mohammad Taleghani ${ }^{*}$, Martin Tenpierik ${ }^{1}$, Andy van den Dobbelsteen ${ }^{1}$, David J. Sailor ${ }^{2}$ \\ 1 Faculty of Architecture and the Built Environment, Delft University of Technology, Delft, the \\ Netherlands \\ 2 Department of Mechanical and Materials Engineering, Portland State University, Portland, OR, USA
}

\begin{abstract}
Natural elements such as vegetation and water bodies may help reduce heat in urban spaces in summer or in hot climates. This effect, however, has rarely been studied during cold seasons. This paper briefly studies the effect of vegetation and water in summer and more comprehensively in winter. Both studies are done in courtyards on two university campuses in temperate climates. A scale model experiment with similar materials supports the previous studies. The summer study is done in Portland (OR), USA, and the winter study (along with the scale model) in Delft, the Netherlands. The summer study shows that a green courtyard at most has a $4.7^{\circ} \mathrm{C}$ lower air temperature in the afternoon in comparison with a bare one. The winter study indicates that the air temperature above a green roof is higher than above a white gravel roof. It also shows that, although a 'black' courtyard has higher air temperatures for a few hours on sunny winter days, a courtyard with a water pond and with high amounts of thermal mass on the ground has a warmer and more constant air temperature in general. Both the summer and winter studies show that parks in cities have a lower and more constant air temperature compared to suburbs, both in summer and winter. The scale model also demonstrates that although grass has a lower albedo than the used gravel, it can provide a cooler environment in comparison with gravels and black roof. ${ }^{1}$
\end{abstract}

\section{Keywords}

Vegetation, water body, summer and winter, courtyard, temperate climates, urban heat island effect, park cool effect.

\footnotetext{
${ }^{1}$ This is a follow up study based on the key findings published by the authors in Building and Environment, Volume 73, March 2014, Pages 138-150.

Corresponding Author:

Mohammad Taleghani

mohamadtaleghani@gmail.com ; m.taleghani@tudelft.nl.

Co-authors contacts:

Martin Tenpierik: m.j.tenpierik@tudelft.nl

Andy van den Dobbelsteen: a.a.j.f.vandendobbelsteen@tudelft.nl

David J. Sailor: sailor@pdx.edu
} 


\section{Introduction}

The urban heat island ( $\mathrm{UHI})$ phenomenon affects the heating and cooling energy demands of buildings in cities and human (and other species') health and thermal comfort. This phenomenon occurs mainly because of the replacement of natural elements (such as vegetation and water bodies) by man-made structures and surfaces that trap and buffer solar heat (asphalt and building materials). Architects and urban designers can alleviate the UHI effect by bringing nature back into the city and urban spaces.

Several studies have shown the ability of vegetation and water bodies in urban environments to reduce $\mathrm{UHI}$ in summer [1-10]; these natural elements may also have an important role in the urban energy balance during winter. In summer, evapotranspiration by vegetation and evaporation from water bodies require heat taken from the surroundings, cooling the nearby ambient air as a result. As an example, a study in an institutional campus in the subtropicalhumid climate of Saga (Japan) showed that the average daily maximum temperature would decrease by $2.7^{\circ} \mathrm{C}$ when the quantity of the trees was increased by $20 \%$ in the campus area [11]. Several other studies have shown the importance of reduced mean radiant temperature by vegetation on outdoor thermal comfort [12-15]. In contrast, during winter, vegetation moderates a microclimate. In combination with sugar, the water within vegetation freezes below $0^{\circ} \mathrm{C}$. Moreover, the roughness of a surface or volume of leaves and grass breaks cold winds, reduces wind chill, and protects stems and roots of plants. The thermal mass of the soil is also an important factor that may result in a higher temperature at night. Table 1 summarises a number of studies that investigated the effect of vegetation and water bodies in summer. Few studies have addressed the effect of green roofs, vegetation and water bodies in winter $[16,17]$. Sailor [18] states that green roofs can increase the heating energy demand of buildings due to their shading effect that is beneficial in summer, but detrimental in winter. The thermal conductivity of water in wet green roofs and the evapotranspiration of vegetation also lead to heat loss [19, 20]. Lazzarin, Castellotti [21] found that a wet green roof has $40 \%$ more outgoing heat flux compared to a typical insulated roof. Furthermore, McPherson, Herrington [22] showed that in cold climates, evergreen plants are not suitable for green roofs in winter because their shading effect reduces solar absorption in winter.

Table 1: The summary of the key findings of different heat mitigation studies in summer.

* Temperature reduction is a result of the presence of the natural element with a bare surrounding.

\begin{tabular}{|c|c|c|c|c|c|}
\hline & Location/ Climate & Season & Natural element & $\begin{array}{l}\text { * Temperature } \\
\text { reduction }\end{array}$ & Reference \\
\hline \multirow{4}{*}{ 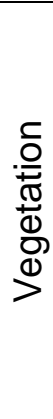 } & $\begin{array}{l}\text { Saga, Japan/ } \\
\text { Subtropical humid }\end{array}$ & Aug 2012 & $\begin{array}{l}20 \% \text { tree } \\
\text { coverage }\end{array}$ & $2.7^{\circ} \mathrm{C} \mathrm{T}_{\mathrm{a}}$ & [11] \\
\hline & $\begin{array}{l}\text { Lisbon, Portugal/ } \\
\text { Subtropical- } \\
\text { Mediterranean }\end{array}$ & Aug 2006 & $\begin{array}{l}0.24 \text { ha green } \\
\text { space }\end{array}$ & $\begin{array}{l}6.9^{\circ} \mathrm{CT}_{\mathrm{a}} \text { and } \\
39.2^{\circ} \mathrm{C} \mathrm{T}_{\mathrm{mrt}}\end{array}$ & [23] \\
\hline & $\begin{array}{l}\text { Göteborg, Sweden/ } \\
\text { Oceanic }\end{array}$ & Summer & Park & $5.9^{\circ} \mathrm{C} \mathrm{T}_{\mathrm{a}}$ & [24] \\
\hline & $\begin{array}{l}\text { Tucson, Arizona/ Hot } \\
\text { dry }\end{array}$ & Summer & 171 ha park & $6.8^{\circ} \mathrm{C} \mathrm{T}_{\mathrm{a}}$ & [25] \\
\hline
\end{tabular}




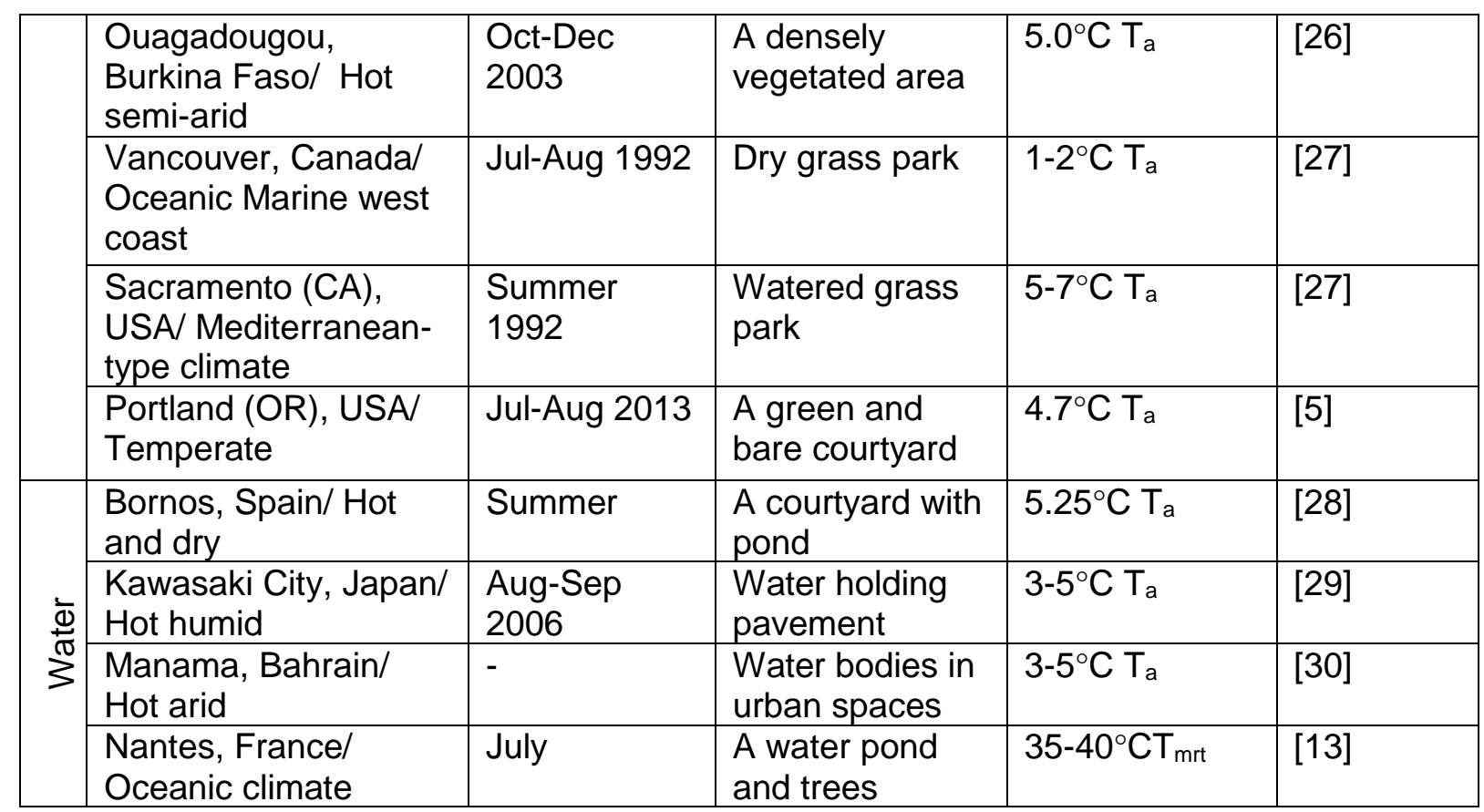

In this research paper, the effect of vegetation and water bodies on microclimates is studied through field measurements in both summer and winter in two university campuses. The summer study (July-August 2013) was done in Portland (OR), USA, and the winter study (November-December 2013) in Delft, the Netherlands; both temperate climates. The field measurements were done within university courtyards because the form of a courtyard provides a protected microclimate that makes the study of different variables such as vegetation and water bodies easier to quantify and compare.

\section{Methodology}

This paper is based on two field measurement campaigns in summer and winter in two similar temperate climates (Figure 1). The main aim was to compare the thermal effect of vegetation and water bodies on the outdoor microclimate in summer and winter. The first case study is in Portland (OR), USA; the second in Delft, the Netherlands.

The summer study was carried out on the campus of Portland State University (an urban campus) in Portland (OR), USA (Figure $2-a$ and b). Portland $\left(45^{\circ} \mathrm{N}, 122^{\circ} \mathrm{W}\right)$ experiences a temperate oceanic climate typified by warm, dry summers and mild, damp winters. The climate of Portland is classified as a dry-summer subtropical or Mediterranean climate zone based on the climatic classification of Köppen-Geiger (Csb) [31]. The mean annual dry bulb temperature is $12.4^{\circ} \mathrm{C}$ and the prevailing wind in summer is from the north-west. In the Portland field study, HOBO U12-006 data loggers were used for the measurements (Figure 2 -c). The accuracy of this device is $\pm 0.25^{\circ} \mathrm{C}$. An air temperature sensor protected by a white solar radiation shield was attached to the HOBO. The position height of the sensor was 1.4 $\mathrm{m}$. The measurements were done in July and August 2013. First, the air temperature and relative humidity were measured in three courtyards on the campus for two weeks. The 
courtyards were bare, with vegetation and with a water pond, respectively. Second, the air temperature of the campus park was measured one week and compared with the suburban areas of the city. For this purpose the weather station of the Airport of Portland (PDX) was selected, which is located at $17 \mathrm{~km}$ distance from the campus (to the north-east).

The winter study was done on the campus of Delft University of Technology (TU Delft), the Netherlands (Figure 2-d and e). The climate of Delft $\left(52^{\circ} \mathrm{N}, 4^{\circ} \mathrm{E}\right)$ is also classified as warm temperate, fully humid, warm summer ( $\mathrm{Cfb})$. In this climate, winters are milder and cloudier than in other climates at similar latitudes, and summers are cool due to cool ocean currents [31]. The mean annual air temperature is $10.3^{\circ} \mathrm{C}$ and the prevailing wind is south-west. The measuring tools in the Delft field study were Escort Junior data loggers that measure air temperature. The accuracy of this device is $\pm 0.3^{\circ} \mathrm{C}$. The data loggers were placed in a bin that was shielded with aluminium cover to minimise the influence of solar radiation (Figure 2f). The measurements took place in November and December 2013. First, the air temperature above three different roofs (green, black and white) was measured at the height of $0.3 \mathrm{~m}$ and compared (for one week with 5 minutes interval). Subsequently, the air temperature in three courtyards was measured for 17 days. The first courtyard had grass on the ground, the second was bare and black (bituminous), and the third courtyard had shrubs and a water pond. Simultaneously, the air temperature of the TU Delft botanical gardens was measured for the same period and compared with the air temperature of Rotterdam-The Hague Airport located $13 \mathrm{~km}$ from the campus to the south-east.

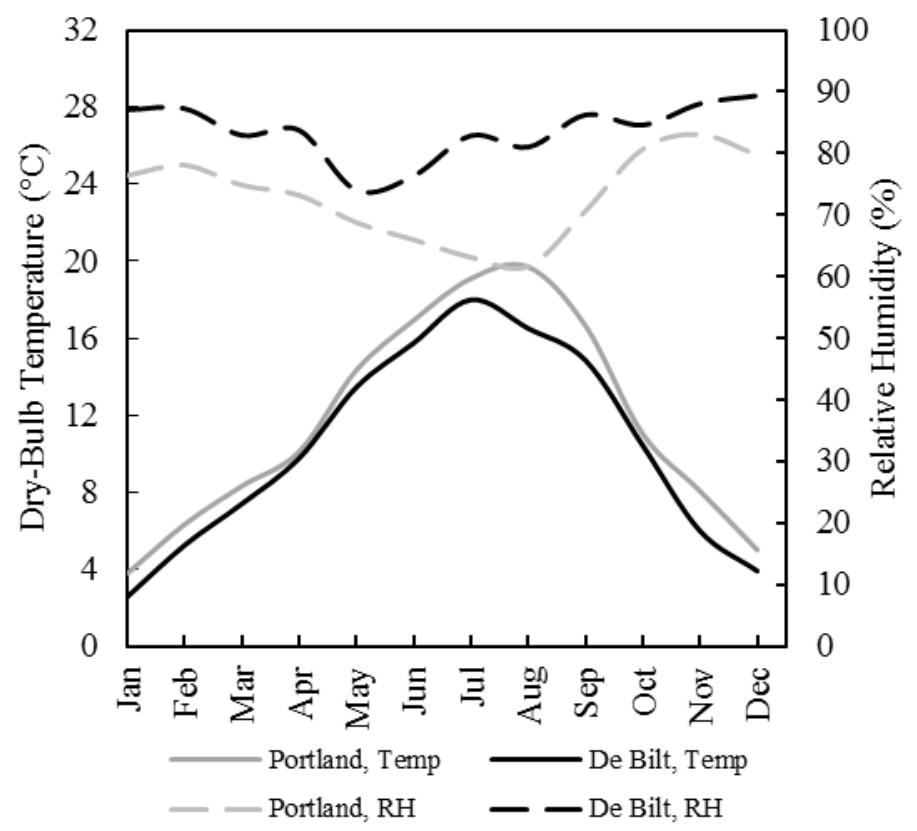

Figure 1: Comparison of air temperature and relative humidity in Portland and Delft [32]. 


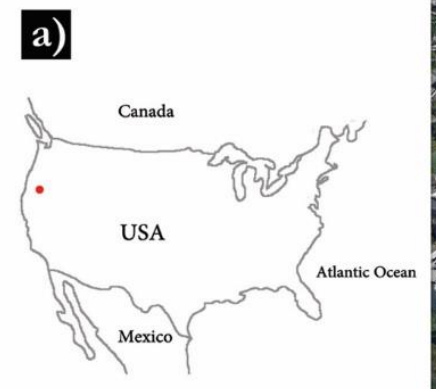

Portland (OR),
USA

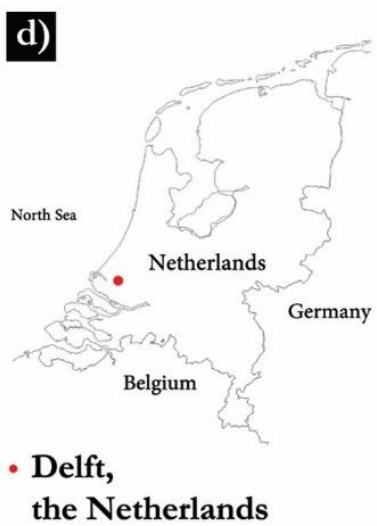

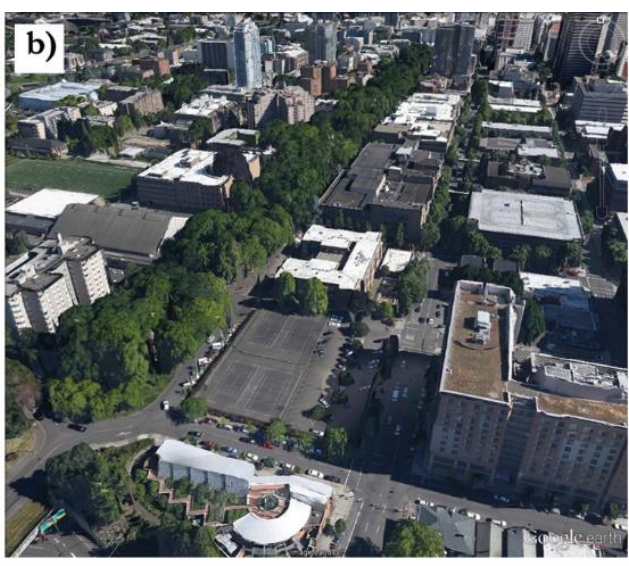
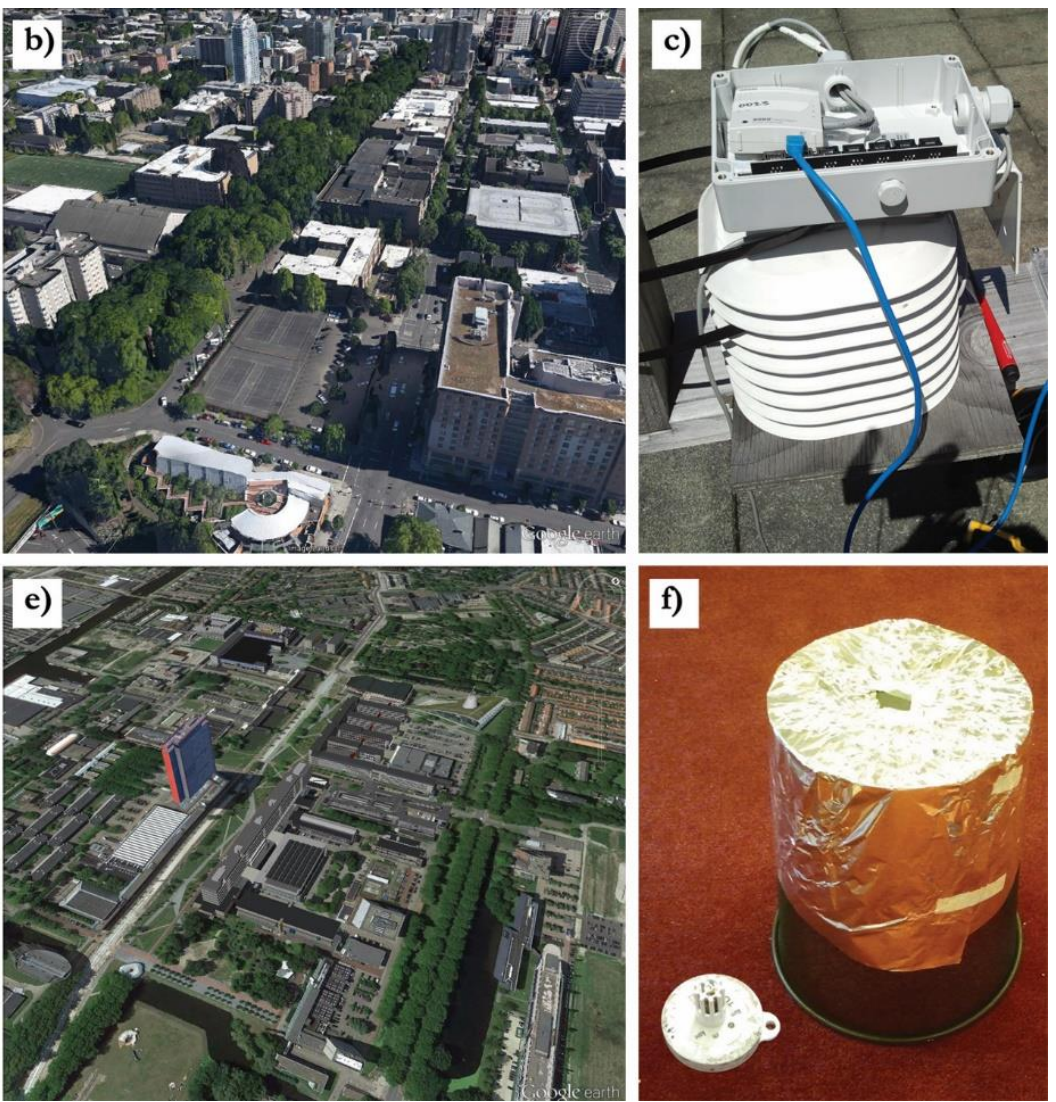

Figure 2: The location of Portland in the US (a). The campus of Portland State University, as the first case study in summer (b). A HOBO data logger used in the summer study (c). The location of Delft in the Netherlands and Europe (d). The campus of Delft University of Technology, as the second case study in winter (e). The Escort data loggers shielded with a bin and used in the winter study (f).

In the last step, a scale model of an urban courtyard was made to test the effects previously measured on roofs and on courtyard grounds in a controlled situation. The only variable in this step is the materials used for paving the roof and the ground of the model. A 1000 Watt lamp was used as the heat source, and a 22 Watt desk fan was used to generate wind (Figure 3). The position of the lamp was similar to the position of the sun on $21^{\text {st }}$ of June in Delft, the Netherlands. The fan blew air to the model from the south-west to simulate the prevailing wind in the Netherlands (also from south-west). Three materials were used to cover the roof and the ground of the courtyard model; black card-board, white gravels and grass (with soil). The gravels and grass were tested two times; dry and wet. Each experiment took 12 hours; 6 hours with the lamp and fan, and 6 hours with the fan. Air temperature was recorded within the courtyard and on the roof with iButtons type DS1923-F5+ temperature sensors. The accuracy of this type of data logger is $\pm 0.5^{\circ} \mathrm{C}$. The experiments were done in April 2014 in a free running mode lab; and therefore, not influenced by heating or cooling systems. The spectral reflectivity and albedo of the materials were also measured with a spectrophotometer (Perkin Elmer Lambda 950- UV/Vis/NIR). Moreover, a FLIR T420bx was used for thermal photography. 


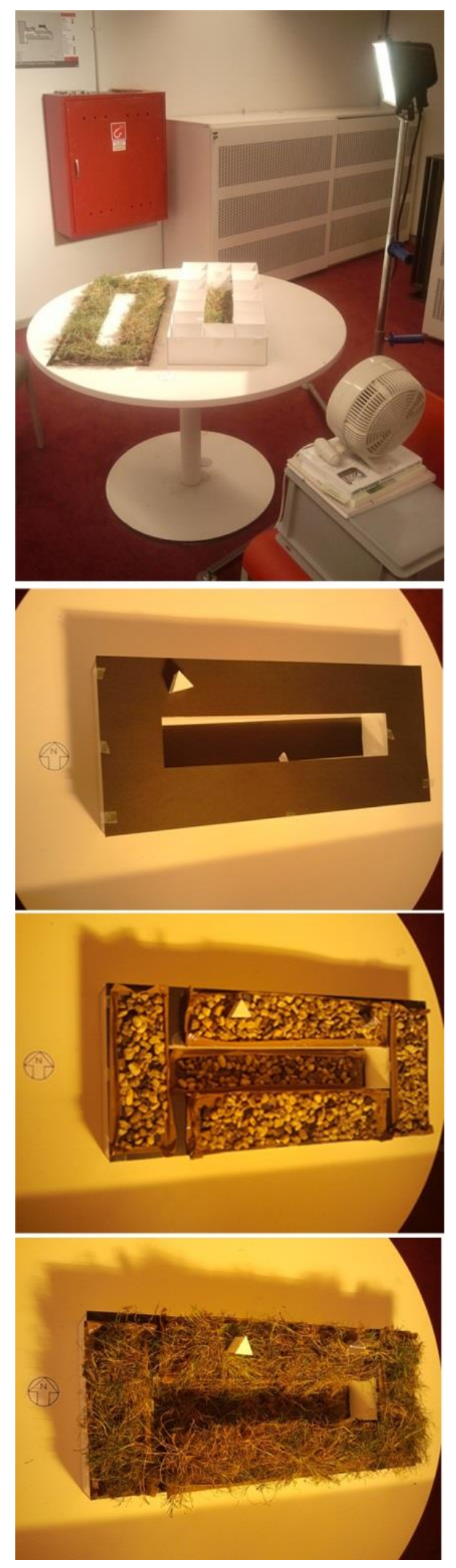

Figure 3: The scale model with three different roofs and courtyard pavements. 


\section{Results and discussion}

\subsection{Summer study, the case of Portland (OR), USA}

\subsubsection{The three different courtyards}

The summer study was carried out in three different courtyards on the campus of Portland State University (OR), USA. The courtyards are green, bare and with a water pond (respectively shown a to $c$ in Figure 4). The green courtyard (5-stories) has shrubs and small trees within the courtard, and the brick walls are covered mostly with climbing plants (ivy). The bare courtyard (1-storey) has brick walls and a concrete pavement. The courtyard with a water pond (3-stories) is also paved with concrete and walls are partly brick partly concrete. The courtyards were measured simultaneously to detect differences in air temperature .

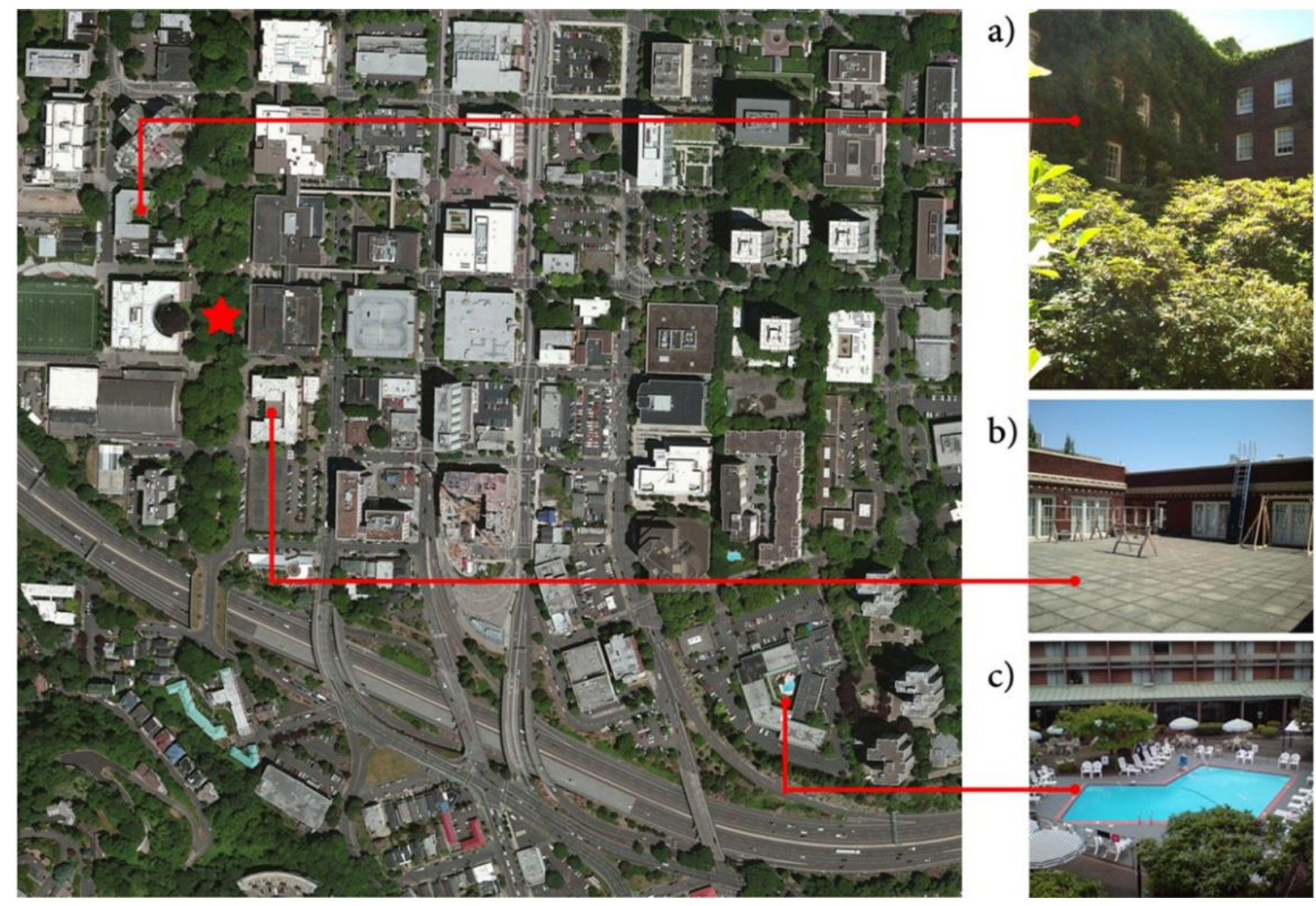

Figure 4: The campus of Portland State University, with indication of the green courtyard (a), the bare courtyard (b), and the courtyard with a water pond (c).

The air temperature recorded during three days in these courtyards is shown in Figure 5 . The bare courtyard has the highest maximum and lowest minimum temperatures. The hottest temperature recorded in this courtyard was $33.3^{\circ} \mathrm{C}$ at $16: 30 \mathrm{PM}$, and the coolest was $15.1^{\circ} \mathrm{C}$ at 6:00 AM. This courtyard therefore has the largest temperature variation in a day $\left(18.1^{\circ} \mathrm{C}\right)$. In contrast, the green courtyard showed the smallest diurnal fluctuation $\left(\Delta T=11.5^{\circ} \mathrm{C}\right)$ with a 
recorded maximum temperature of $28.7^{\circ} \mathrm{C}$ at $18: 00 \mathrm{PM}$. The maximum temperature difference was found between the bare and green courtyard at $16: 30 \mathrm{PM}$ with $4.7^{\circ} \mathrm{C}$ (on August $6^{\text {th }}$, the sunset was at 19:57 PM).

With reference to the bare courtyard the higher albedo of vegetation of the green courtyard and their evapotranspiration effect causes the lower air temperature. The temperature measured in the courtyard with a water pond turned out to be in between. This courtyard has a combination of the other courtyards' characteristics: high thermal mass and the evaporation of the water pond. During the nights, both the courtyard with a water pond and the green courtyard, which have more thermal mass, release their heat slowly to the microclimate, making their environment warmer than inside the bare courtyard. Moreover, trees and shrubs reduce the re-radiation of heat from the ground to the sky.

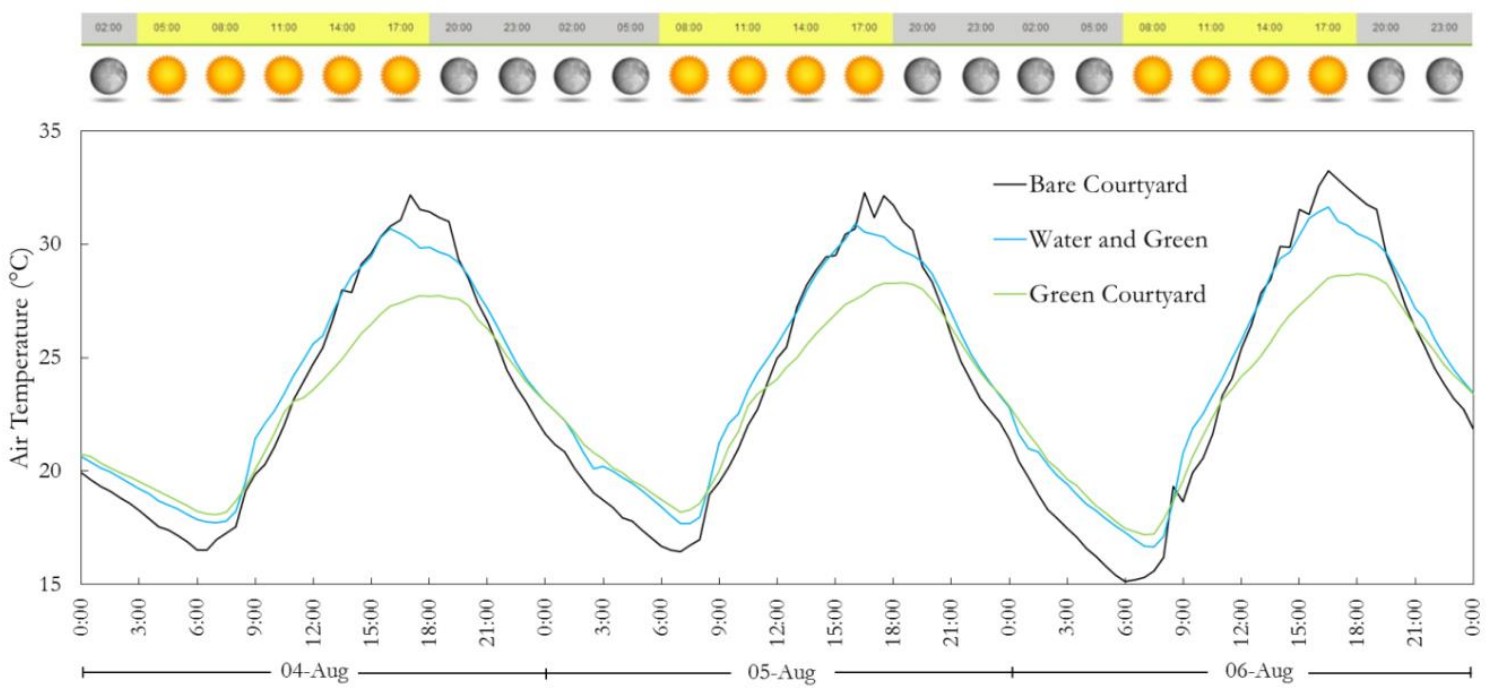

Figure 5: The air temperature compared in the three Portland courtyards.

\subsubsection{Park cool effect in Portland}

Figure 4 shows the location of the park on the campus. The area of the park is $46 \mathrm{~m}$ by 950 $\mathrm{m}$. The air temperature of the park was compared with the air temperature recorded by the Portland Airport (PDX) weather station located in a suburban area. As Figure 6 shows, the airport has a larger diurnal variation in air temperature than the park, with warmer peaks and cooler pits. The maximum temperature during the measurements at the airport was $31.1^{\circ} \mathrm{C}$ (at 16:00 and 16:30 PM) while it was $26.2^{\circ} \mathrm{C}$ in the park at the same time. The lowest temperature recorded at the airport was $11.7^{\circ} \mathrm{C}$, and in the park $14.6^{\circ} \mathrm{C}$ (at $6: 00$ and $6: 30$ $\mathrm{AM}$; sunrise was at 5:50 AM). As mentioned, the diurnal variation of air temperature at the airport was larger than in the park. The maximum difference occurring during the day was $5.0^{\circ} \mathrm{C}$ and $3.0^{\circ} \mathrm{C}$ during the night. 


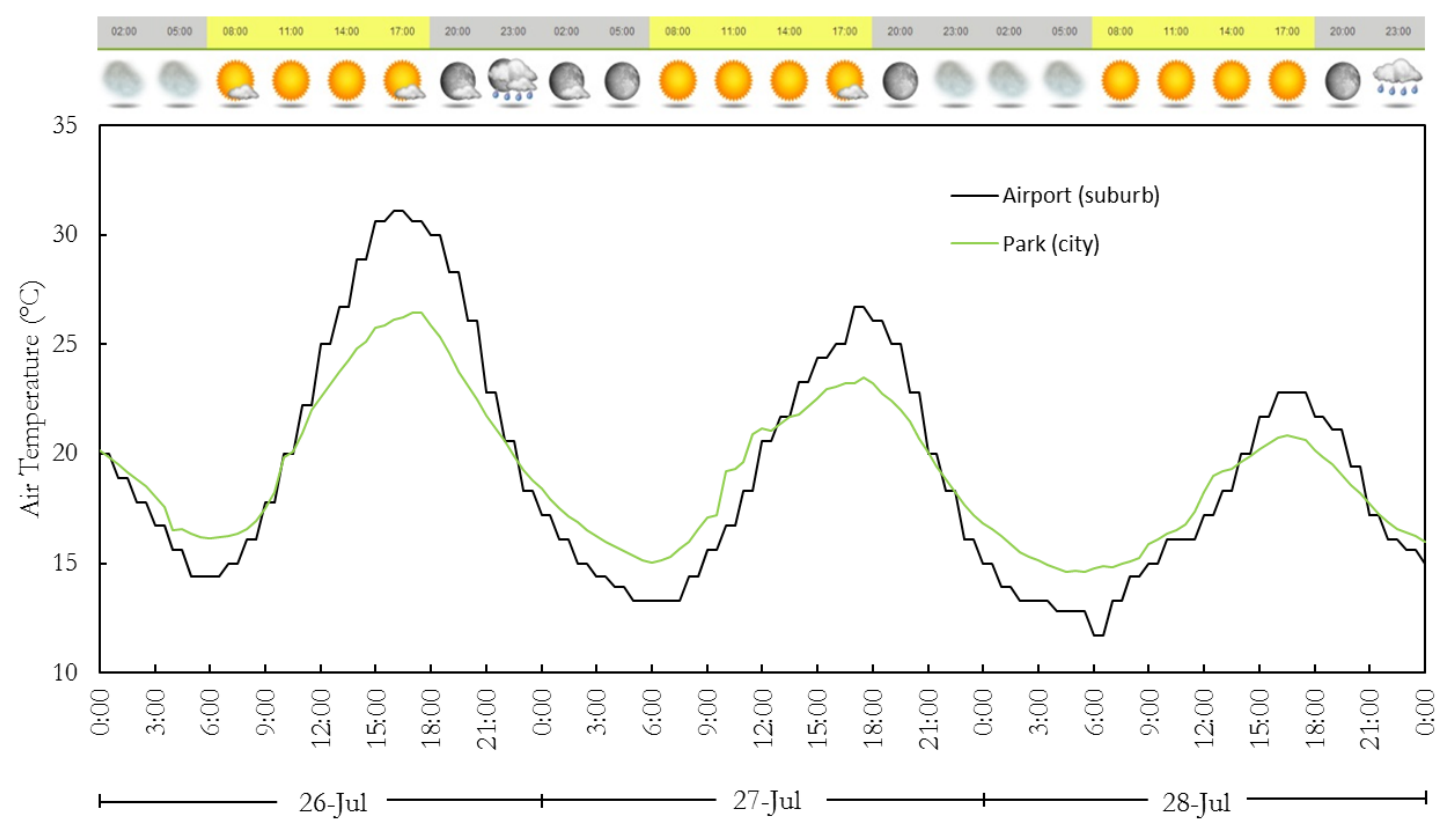

Figure 6: The air temperature compared between the Portland campus park and the airport in a suburban area.

\subsection{Winter study, the case of Delft, the Netherlands}

\subsubsection{The three different courtyards}

As a next step, three different courtyards were measured between the $15^{\text {th }}$ of November and $30^{\text {th }}$ of December 2013 on the campus of TU Delft (Figure 7). The first courtyard $\left(30 * 31 \mathrm{~m}^{2}\right)$ is covered with grass and has two trees (a). The second one (b) has black bitumen $\left(30^{*} 58\right.$ $\left.\mathrm{m}^{2}\right)$, and the third one (c) has a water pond and shrubs $\left(15^{\star} 19 \mathrm{~m}^{2}\right)$. The orientation of these three courtyards is from North-East to South-West. The air temperature was recorded at a height of $1 \mathrm{~m}$ above the ground every 30 minutes. Figure 8 shows the air temperature in the courtyards during four representative days.

During the first two days, which were sunny, the black courtyard had a higher air temperature. This is due to the black colour and consequently lower albedo of the surfaces. Moreover, the very low thermal mass of the surface causes the large diurnal fluctuations. During the next two rainy days, this courtyard did not show the highest temperature among the courtyards. Instead, the courtyard with water pond and shrubs had the highest air temperature. This courtyard is paved with concrete mosaic and is the smallest of the three (making it more protected against the wind). The heat capacity of the ground in addition to the radiated heat from the surrounding building and the lower wind speeds keeps the courtyard warmer than the others. The green courtyard covered with grass has the lowest temperature in general; however, the minimum recorded temperature occurred in the black courtyard $\left(1.4^{\circ} \mathrm{C}\right)$. Considering Figure 7 , the green courtyard is close to the botanical garden, and this adjacency can lower the ambient air temperature around the courtyard. 
It should be mentioned that the geometry of the courtyard is also a key factor in the thermal behaviour of these microclimates. The green courtyard is 3 stories high (the deepest among the others) and its solar gain is lower than of the others. The black courtyard (with 1 storey building) is open from one side (South-East), which means it can receive early morning sun and is prone to more ventilation. The black courtyard has 1 story and the courtyard with water pond has a 2-story building around it.

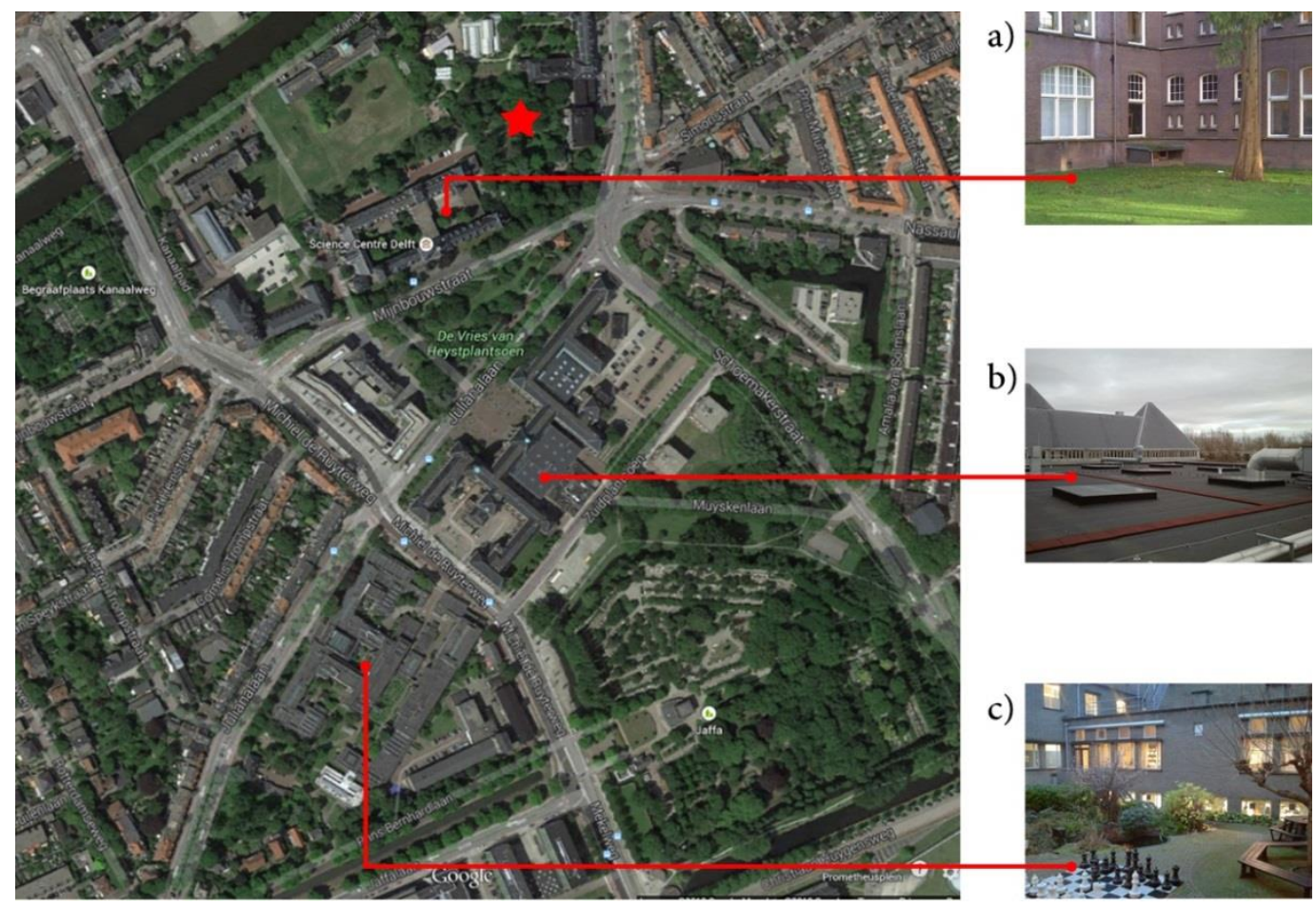

Figure 7: The three courtyards measured in Delft (numbered a to c) and the botanical garden highlighted with a star.

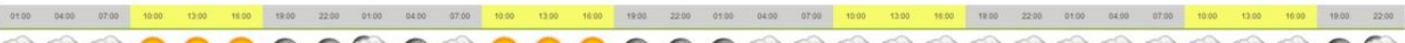

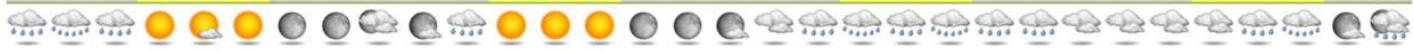

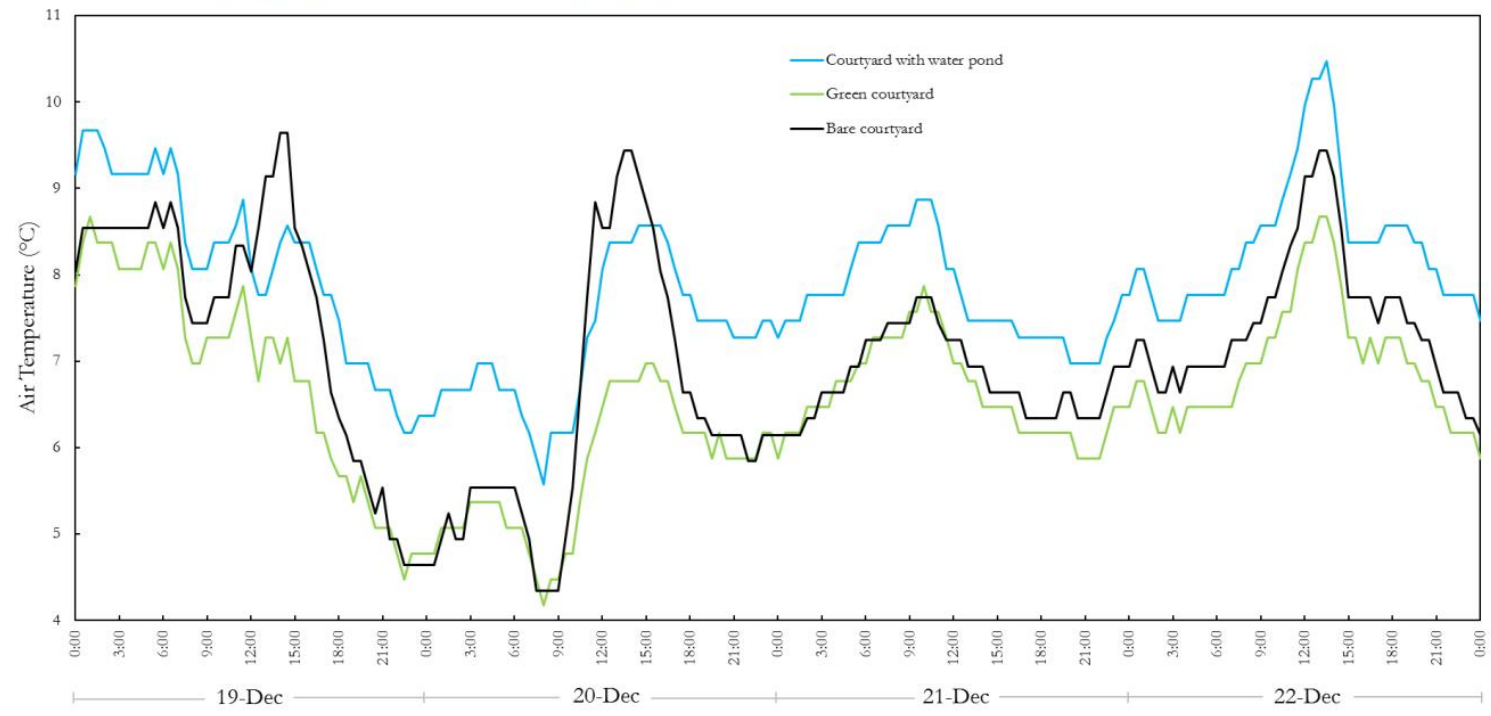

Figure 8: The air temperature measured in the Delft courtyards. 


\subsubsection{Park cool effect in Delft}

It is normally expected that city centres have a higher nocturnal air temperature than their suburbs because of the urban heat island phenomenon [33,34]. Most of the time differences between the two areas are compared during summer because of the effect on heat stress and the buildings' energy consumption. Instead of a city centre, this research investigates the thermal situation in a park located in a city centre in comparison with the suburbs. The air temperature in the botanical gardens of the university campus was compared with the rural area of Delft in winter. An appropriate weather station is Rotterdam-The Hague Airport at 13 $\mathrm{km}$ distance from the botanical gardens to the South-East. The measurements were taken between the $13^{\text {th }}$ of November and 30

The data is compared in Figure 9, showing that the airport located outside of the city always has a slightly higher air temperature in general. The trend of daily peaks in the botanical gardens is the same as at the airport, however with a short delay. This delay might be due to the thermal mass of the city. It means that the airport is in an open area that receives solar radiation freely and therefore gets warm faster than an area with higher thermal mass with different urban geometries and shading. The maximum air temperature recorded at the airport was $10^{\circ} \mathrm{C}$, and $1^{\circ} \mathrm{C}$ less in the gardens with a time delay of 2 or 3 hours. It should also be mentioned that weather stations record the air temperature at $1.5 \mathrm{~m}$ above the ground. In the botanical gardens, the air temperature was measured at a height of $1 \mathrm{~m}$. The openness to the sky of the airport and the limited thermal mass causes faster loss of heat at night. Therefore, the slopes towards the highest and lowest temperatures are steeper at the airport. The minimum air temperature recorded at the airport was $4.1^{\circ} \mathrm{C}$ at 7:00 AM (before the sun rises at 8:48 AM). At that moment, the botanical gardens had an air temperature of $4.8^{\circ} \mathrm{C}$.

The botanical gardens and the airport also have different range in diurnal temperature variation. A small range indicates that the recorded diurnal temperature fluctuations are small. In these two areas, the difference between the maximum and minimum values of the air temperature of the gardens is $4.5^{\circ} \mathrm{C}$, and $5.9^{\circ} \mathrm{C}$ at the airport. This indicates that the botanical gardens have a slightly more stable microclimate than the airport.

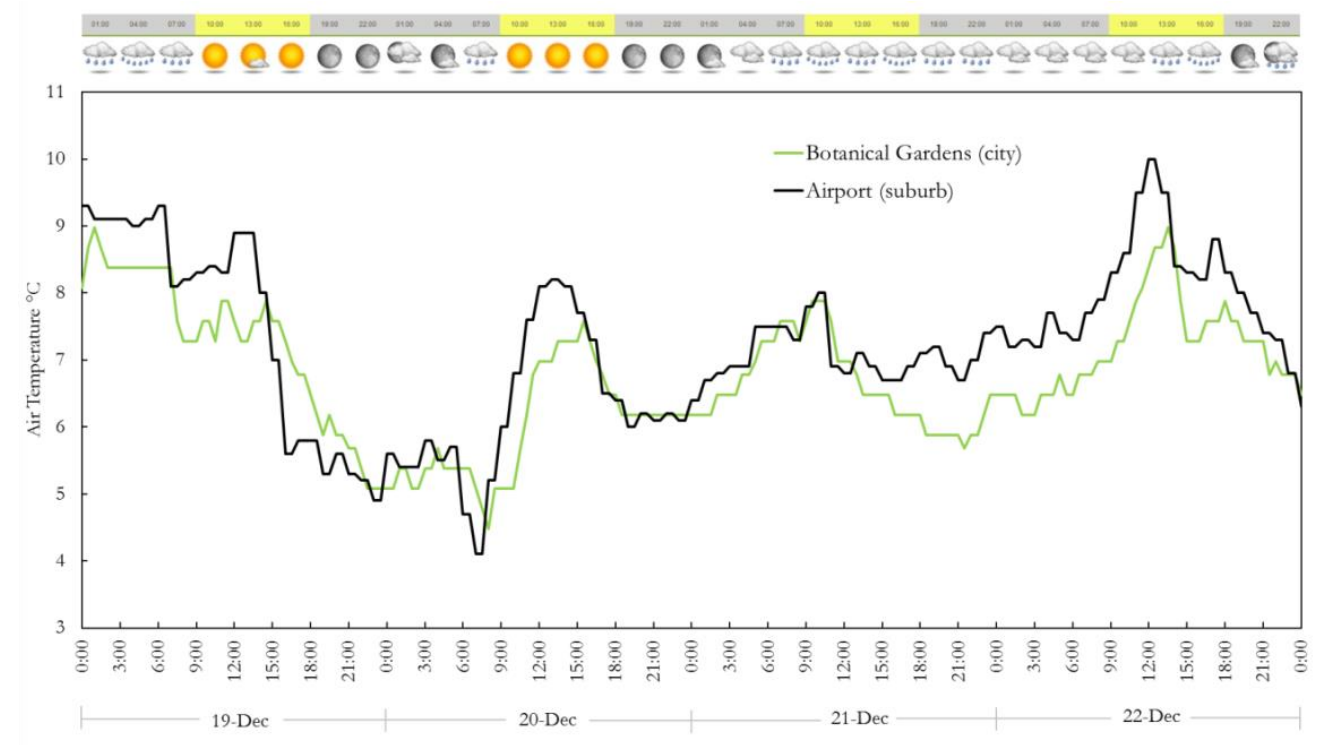

Figure 9: A comparison of the air temperature in the botanical gardens of Delft and at Rotterdam-The Hague airport in a suburban area. 


\subsubsection{Three different roofs}

The measurements on the three different roofs were done in the first two weeks of December 2013. The maximum sun angle on the $21^{\text {st }}$ of December (the shortest day of the year) in Delft is $15^{\circ}$ at noon. In the two measurement weeks, the air temperature above three different roofs was measured with a 10 minute time interval (Figure 10). The room under the green roof (with sedum plants) is an exam hall, the black roof (with bitumen) accommodates a meeting room, and under the white roof (with gravel) offices can be found. The heating system of these spaces is the same (radiators) and it is off between 18:00 and 6:00. The characteristics and the peak temperatures recorded are summarised in Table 2, and the temperatures recorded are shown in Figure 11.

The black roof leads to the relatively highest air temperature right above its surface during the day because this roof has the lowest albedo and therefore high solar radiation absorption. Moreover, the thermal mass of this roof is very low as a result of which the roof can heat up very rapidly. However, the difference between the air temperatures above the three roofs is very small. It is close to the inaccuracy of the equipment, as a result of which this conclusion should be treated with some caution. Considering the sunny and cloudy days, it is visible that the solar radiation has a strong effect on the day temperature of the roofs. However, what is clearly noticeable is that during the afternoon the white roof loses its heat faster than the other roofs. Because of the low sun angle in the afternoon in December, this roof becomes shaded much sooner than the other two roofs. Furthermore, in combination with wind the open porous structure of the gravel, hence the large exposed surface area of the gravel, makes the cooling process more rapid. During the nights, this roof is the coolest and the green roof is the warmest.

The green roof is shown in Figure 12. This roof is protected by a glazed wall (as illustrated in Figure 12) and it is less prone to heat loss through the wind. Moreover, the thermal mass of the green roof (the soil) releases heat during the night. The lowest temperature of the green roof was always above zero while the white roof reached $-0.4^{\circ} \mathrm{C}$.

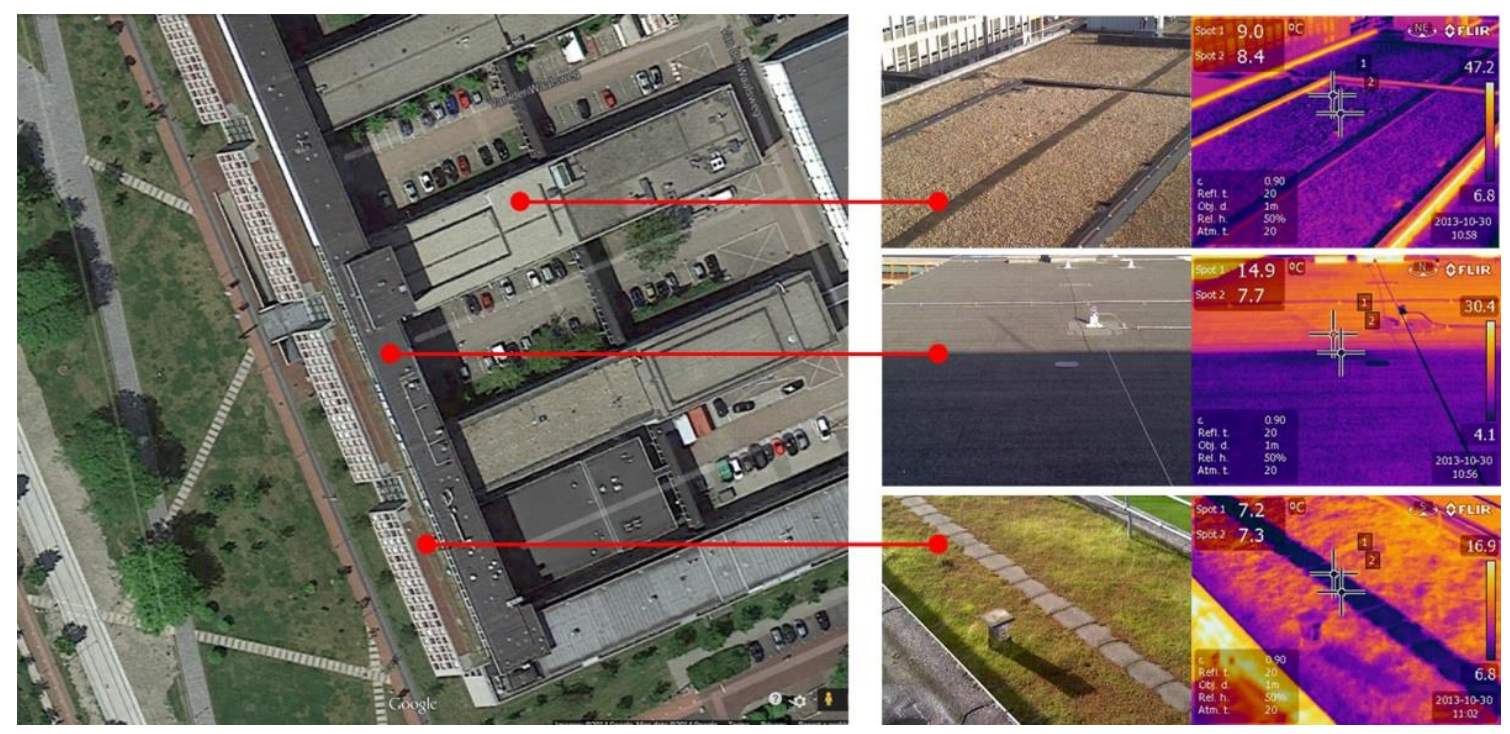

Figure 10: The roofs measured in Delft. 


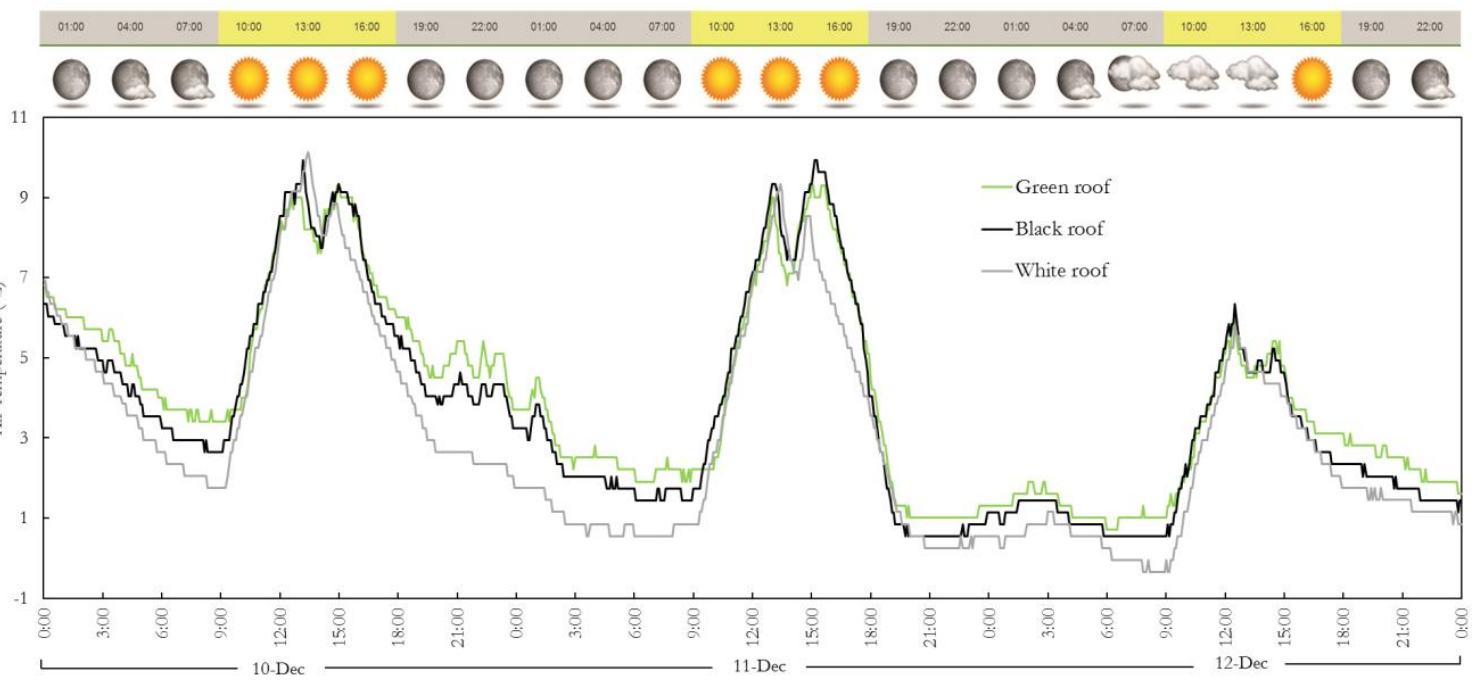

Figure 11: The temperatures recorded above of the roofs.

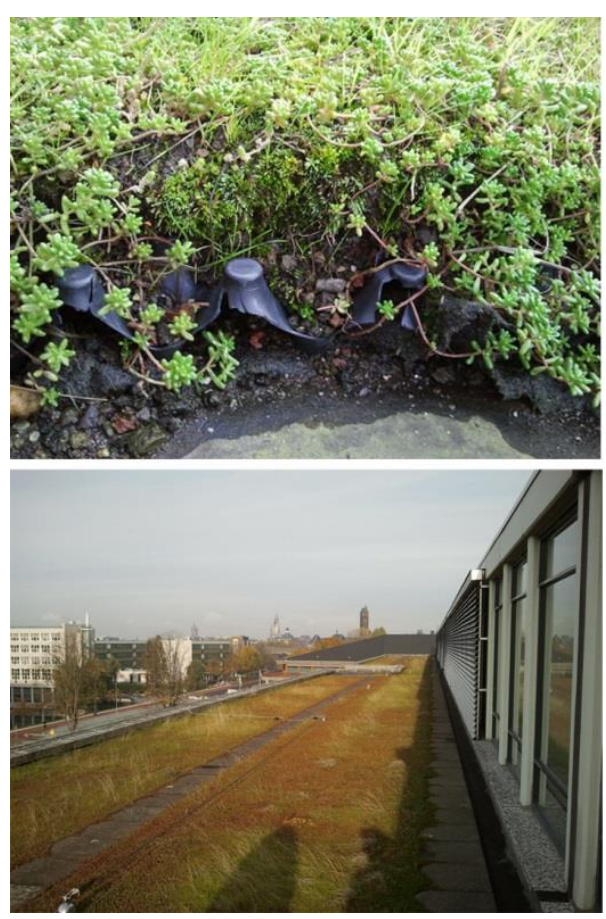

Figure 12: The green roof.

Table 2: The characteristics and peak temperatures of the Delft roofs.

\begin{tabular}{|l|c|c|c|}
\hline & black roof & green roof & white roof (gravel) \\
\hline Albedo & 0.10 & 0.20 & 0.72 \\
\hline Emissivity & 0.93 & 0.98 & 0.28 \\
\hline Max temperature $\left({ }^{\circ} \mathrm{C}\right)$ & 25.9 & 25.6 & 25.8 \\
\hline Min temperature $\left({ }^{\circ} \mathrm{C}\right)$ & 0.5 & 0.7 & -0.4 \\
\hline
\end{tabular}




\subsection{Scale model experiment}

Although the previous studies were done on real cases, they may have been influenced by other unsought factors (such as different user activities and different adjacency to parks). In this lab experiment, the only variable was the material used to cover the roof and the ground of the courtyard model. The materials used were black cardboard, whitish gravels and grass. Gravels and grass were measured dry and wet (five experiments in total). The albedo of the black cardboard is 0.054 , and the grass in dry mode is 0.387 (both measured). The albedo of the gravels based on Santamouris [35] is 0.72 .

Figure 13 shows the normalised air temperature within the courtyard model and above the roof. To get these normalised values, the ambient air temperature of the lab was subtracted from the measured air temperatures right above the roofs and courtyard grounds $(5 \mathrm{~mm}$ above the surface). A value above zero thus means that the air above the surface is warmer than the lab air temperature, vice versa. The temperatures are plotted after 6 and 12 hours. The lamp (representing the sun) was turned off after 6 hours, and the fan (as the wind source) was turned off after 12 hours, at the end of each experiment.

Concerning the roof of the model, the black pavement (with the lowest albedo and mass) has provided the highest temperature difference $\left(+2.7^{\circ} \mathrm{C}\right)$ after 6 hours of heating with the lamp. The dry gravel roof has the second highest temperature; however, when this roof was irrigated, its temperature dropped down and became cooler than the ambient air temperature $\left(-0.7^{\circ} \mathrm{C}\right)$. The dry and wet grass roofs were also cooler than the ambient air temperature. This study did not find a significant difference between the dry and irrigated grass roof. This may have been caused by water still present in the soil of the dry grass. Nevertheless, it is found that grass in wet and dry mode is cooler than the ambient; however, gravels need to be watered to provide a cooler temperature.

Regarding the courtyard temperatures, the dry gravels and the black pavements have the highest temperature difference after 6 hours $\left(+1.9^{\circ} \mathrm{C}\right.$ and $+1.7^{\circ} \mathrm{C}$, respectively). Comparing the dry gravels and grass with their wet situation, the dry pavements have higher temperature in both materials, after 6 and 12 hours. When the gravel pavement is irrigated, its temperature difference with the dry mode $\left(4.2^{\circ} \mathrm{C}\right)$ is much higher than the difference between the dry and wet grass $\left(2.9^{\circ} \mathrm{C}\right)$. After 12 hours of monitoring, the wet grass pavement has the lowest temperature $\left(-3.2^{\circ} \mathrm{C}\right)$ among the others. The other cool pavement material was the wet gravels with $-2.9^{\circ} \mathrm{C}$, and there was no significant temperature difference between the dry gravels and the black pavement.

About the effect of albedo on the microclimate of the scale model, this experiment shows that gravels (with the highest albedo) do not necessarily provide the coolest environment. The evapotranspiration effect of grass can provide a cooler temperature on the roof and within the courtyard. 

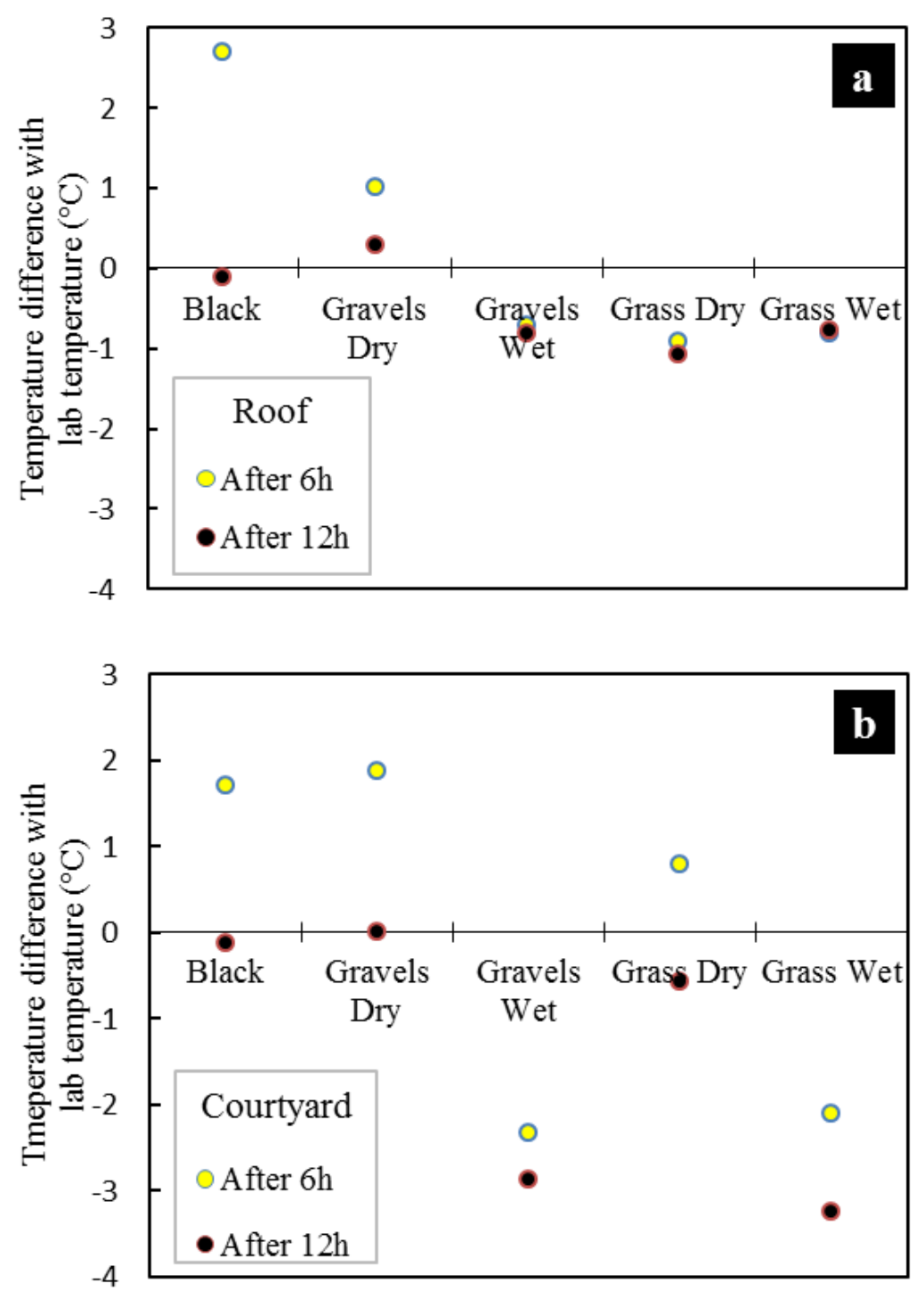

Figure 13: Temperatures above the roof (a) and within the courtyard model (b).

\section{Conclusions}

This paper investigated the thermal effect of vegetation and water bodies in summer and winter in two temperate climates: that of Portland (OR) in the USA and Delft in the Netherlands. Two university campuses were selected for the field measurements. An experiment on a scale model was done after these measurements.

In the summer study, the bare courtyard demonstrated to have the warmest temperature in comparison with the courtyards with vegetation and a water body. The bare courtyard also had the lowest air temperature during the night. The green courtyard exerted the inverse behaviour because the vegetation blocks the sun during the day. During the night, trees and shrubs reduce the re-radiation of heat from the ground to the sky.

The temperature of the Portland campus park was compared with a suburb of the city. It was experienced that compared to the park the airport located in a free field had a higher 
temperature during the day and lower temperature during the night. In this case, it was also observed that the park had less diurnal air temperature fluctuation in comparison with the airport.

In the winter study, similar measurements were carried out. The air temperature in three courtyards was measured. One courtyard is bare and with black pavement, one has grass on the ground and the third has shrubs, concrete tiles and a water pond. The third courtyard, which is the smallest, had the highest temperature on cloudy days. The black bare courtyard was the warmest only on sunny days around noon.

The ambient air temperature above three different roofs (green, black and white) was also measured. The black roof had the highest temperature during the day, and the green roof the highest during the night. The white roof had the lowest temperature during the day and during the night.

Furthermore, in winter the air temperature of a garden on the campus of Delft University of Technology was compared with the air temperature at Rotterdam-The Hague Airport. Similar as in the summer study in Portland, the airport had the highest temperature during the day and the lowest during the night. The airport again exhibited higher temperature fluctuations while the park had a more stable air temperature.

The scale model also confirmed that a green pavement with grass on a courtyard or a roof leads to the lowest temperature in comparison with gravels and black material. The experiment also showed that irrigated grass and gravels have better cooling effect.

Finally, from these field experiments, the following conclusions can be derived:

- In temperate climates as in Portland, vegetation in the form of short trees in combination with climbing plants can reduce the ambient air temperature up to $4.7^{\circ} \mathrm{C}$ during the late afternoon in summer. For urban spaces with night activities, water ponds are another good strategy to absorb the heat during the day and release it again during the night to make the microclimate moderate.

- The study in Delft showed that in wintertime black and green roofs have higher temperature than a white roof. This finding is useful for the climates in which heating has a higher priority than the cooling.

- The results of the different courtyards in summer and winter are in accordance with the previous studies on urban spaces with different surface properties. Although choosing a dark surface helps the microclimate of the courtyard to be warmer in winter in few hours, a green courtyard has a more stable temperature due to the evapotranspiration of the vegetation and the humidified air.

- Both studies in summer and winter showed that parks with trees have a more constant air temperature during a day in comparison with suburbs. The temperature in a park in the city centre is generally lower than the temperature in bare suburbs. Other studies have compared and showed city centres have higher temperature than suburbs. Therefore, this paper suggests that university campuses located in city centres with their open spaces have the potential to mitigate urban heat island by adding more vegetation and water bodies.

- The experiment on the scale model showed that vegetation with lower albedo has a stronger cooling effect than gravels. 
One important finding from this study is that in terms of their temperature effect roofs and courtyards do not behave significantly differently in winter than in summer. Prior research has focused mainly on the effect in summer. This research demonstrates that similar effects can be observed in wintertime.

\section{Appendix}

Figure 14 shows the surface temperature of the materials used in the scale model after 7 hours of radiation with the lamp (and wind with the fan). The surface temperature of the black, dry grass, wet grass, wet gravels and dry gravels are $28.1^{\circ} \mathrm{C}, 27.8^{\circ} \mathrm{C}, 20.9^{\circ} \mathrm{C}, 24.5^{\circ} \mathrm{C}$ and $28.1^{\circ} \mathrm{C}$, respectively. This figure illustrates that irrigated grass and gravels have a cooler surface than their dry mode. The dry gravels have the same temperature as the black surface.

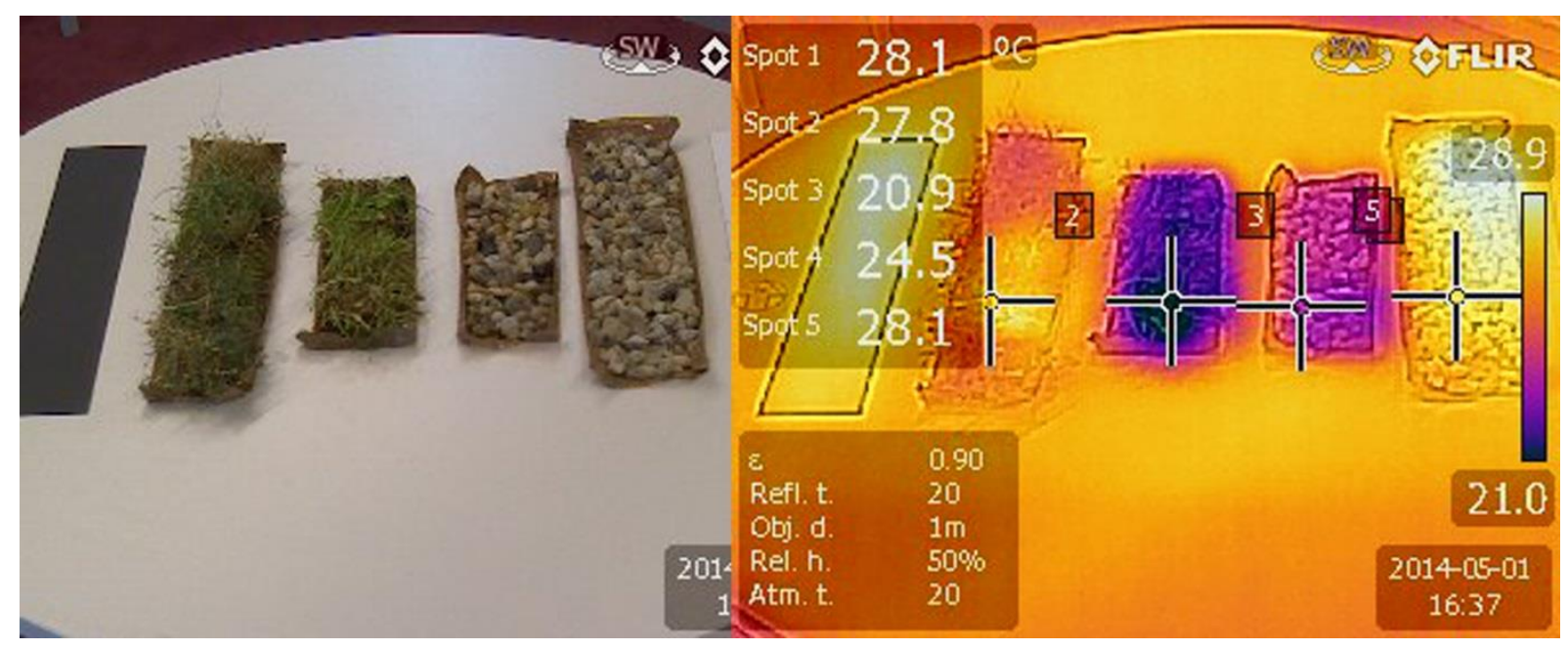

Figure 14: Comparison of the materials used in the scale model experiment.

\section{Acknowledgement}

The authors appreciate cooperation and consultation of Dr. Bob Ursem from the Botanic Garden of Delft University of Technology.

\section{References}

1. Oke, T.R., Boundary Layer Climates. 2002: Taylor \& Francis.

2. Rosenfeld, A.H., et al., Mitigation of urban heat islands: materials, utility programs, updates. Energy and Buildings, 1995. 22(3): p. 255-265. 
3. Scherba, A., et al., Modeling impacts of roof reflectivity, integrated photovoltaic panels and green roof systems on sensible heat flux into the urban environment. Building and Environment, 2011. 46(12): p. 2542-2551.

4. Lin, T.-P., A. Matzarakis, and R.-L. Hwang, Shading effect on long-term outdoor thermal comfort. Building and Environment, 2010. 45(1): p. 213-221.

5. Taleghani, M., et al., Thermal assessment of heat mitigation strategies: The case of Portland State University, Oregon, USA. Building and Environment, 2014. 73: p. 138-150.

6. Montazeri, H., B. Blocken, and J.L.M. Hensen, Evaporative cooling by water spray systems: CFD simulation, experimental validation and sensitivity analysis. Building and Environment. 78.

7. Erell, E., D. Pearlmutter, and T.J. Williamson, Urban Microclimate: Designing the Spaces Between Buildings. 2012: Earthscan.

8. Taleghani, M., et al., Outdoor thermal comfort within five different urban forms in the Netherlands. Building and Environment. In Press.

9. Santamouris, M., et al., Using cool paving materials to improve microclimate of urban areas Design realization and results of the flisvos project. Building and Environment, 2012. 53(0): p. 128-136.

10. Taha, H., et al., Residential cooling loads and the urban heat island-the effects of albedo. Building and Environment, 1988. 23(4): p. 271-283.

11. Srivanit, M. and K. Hokao, Evaluating the cooling effects of greening for improving the outdoor thermal environment at an institutional campus in the summer. Building and Environment, 2013. 66(0): p. 158-172.

12. Shahidan, M.F., et al., An evaluation of outdoor and building environment cooling achieved through combination modification of trees with ground materials. Building and Environment, 2012. 58(0): p. 245-257.

13. Robitu, M., et al., Modeling the influence of vegetation and water pond on urban microclimate. Solar Energy, 2006. 80(4): p. 435-447.

14. $\mathrm{Ng}$, E., et al., A study on the cooling effects of greening in a high-density city: An experience from Hong Kong. Building and Environment, 2012. 47(0): p. 256-271.

15. Coutts, A.M., et al., Assessing practical measures to reduce urban heat: Green and cool roofs. Building and Environment, 2013. 70(0): p. 266-276.

16. Jim, C.Y., Passive warming of indoor space induced by tropical green roof in winter. Energy, 2014. 68(0): p. 272-282.

17. Lin, B.-S., et al., Impact of climatic conditions on the thermal effectiveness of an extensive green roof. Building and Environment, 2013. 67(0): p. 26-33.

18. Sailor, D.J., A green roof model for building energy simulation programs. Energy and Buildings, 2008. 40(8): p. 1466-1478.

19. Zhao, M. and J. Srebric, Assessment of green roof performance for sustainable buildings under winter weather conditions. Journal of Central South University, 2012. 19(3): p. 639644.

20. Taleghani, M., et al., Heat in courtyards: $A$ validated and calibrated parametric study of heat mitigation strategies for urban courtyards in the Netherlands. Solar Energy, 2014. 103: p. 108-124.

21. Lazzarin, R.M., F. Castellotti, and F. Busato, Experimental measurements and numerical modelling of a green roof. Energy and Buildings, 2005. 37(12): p. 1260-1267.

22. McPherson, E.G., L.P. Herrington, and G.M. Heisler, Impacts of vegetation on residential heating and cooling. Energy and Buildings, 1988. 12(1): p. 41-51.

23. Oliveira, S., H. Andrade, and T. Vaz, The cooling effect of green spaces as a contribution to the mitigation of urban heat: A case study in Lisbon. Building and Environment, 2011. 46(11): p. 2186-2194. 
24. Upmanis, H., I. Eliasson, and S. Lindqvist, The influence of green areas on nocturnal temperatures in a high latitude city (Göteborg, Sweden). International Journal of Climatology, 1998. 18(6): p. 681-700.

25. Spronken-Smith, R.A., Energetics and cooling in urban parks. 1994, The University of British Columbia, Vancouver. p. 204 pp.

26. Lindén, J., Nocturnal Cool Island in the Sahelian city of Ouagadougou, Burkina Faso. International Journal of Climatology, 2011. 31(4): p. 605-620.

27. Spronken-Smith, R.A. and T.R. Oke, The thermal regime of urban parks in two cities with different summer climates. International Journal of Remote Sensing, 1998. 19(11): p. 20852104.

28. Reynolds, J.S. and V. Carrasco, Shade water and mass: Passive cooling in Andalucia, in National Passive Solar Conference. 1996, American Solar Energy Society: Boulder, CO.

29. Nakayama, T. and T. Fujita, Cooling effect of water-holding pavements made of new materials on water and heat budgets in urban areas. Landscape and Urban Planning, 2010. 96(2): p. 57-67.

30. Radhi, H., F. Fikry, and S. Sharples, Impacts of urbanisation on the thermal behaviour of new built up environments: $A$ scoping study of the urban heat island in Bahrain. Landscape and Urban Planning, 2013. 113(0): p. 47-61.

31. Kottek, M., et al., World Map of the Köppen-Geiger climate classification updated. Meteorologische Zeitschrift, 2006. 15(3).

32. Weather Data. 2012 16.07.2012]; Weather Data]. Available from: http://apps1.eere.energy.gov/buildings/energyplus/cfm/weather data3.cfm/region=6 euro pe wmo region $6 /$ country=NLD/cname=Netherlands.

33. Santamouris, M., et al., On the impact of urban climate on the energy consumption of buildings. Solar Energy, 2001. 70(3): p. 201-216.

34. Taha, H., Meso-urban meteorological and photochemical modeling of heat island mitigation. Atmospheric Environment, 2008. 42(38): p. 8795-8809.

35. Santamouris, M., Environmental Design of Urban Buildings: An Integrated Approach. 2012: Taylor \& Francis. 